\title{
Frequency Distribution of Cutaneous Leishmaniasis in the Central Region of Iran
}

\section{İran Merkez Bölgesinde Kutanöz Leishmaniasis’in Frekans Dağlımı}

\author{
(D) Jamshid Ayatollahi ${ }^{1,2}$, (1) Zahra Aghaee ${ }^{3}$, (D) Aliakbar Tajfiruzeh ${ }^{4}$, (D) Seyed Hossein Shahcheraghi ${ }^{1}$ \\ ${ }^{1}$ Infectious Diseases Research Center, Shahid Sadoughi Hospital, Shahid Sadoughi University of Medical Sciences, \\ Infectious Diseases, Yazd, Iran \\ ${ }^{2}$ Zoonotic Diseases Research Center, Department of Food Hygiene and Safety, School of Public Health, Shahid \\ Sadoughi University of Medical Sciences, Yazd, Iran \\ ${ }^{3}$ Medical Student, Shahid Sadoughi University of Medical Sciences, Medicine, Yazd, Iran \\ ${ }^{4}$ Leishmaniasis Expert, Shahid Sadoughi University of Medical Sciences, Infectious Diseases, Yazd, Iran
}

Cite this article as: Ayatollahi J, Aghaee Z, Tajfiruzeh A, Shahcheraghi SH. Frequency Distribution of Cutaneous

Leishmaniasis in the Central Region of Iran. Turkiye Parazitol Derg 2021;45(1):45-48

\begin{abstract}
Objective: Cutaneous leishmaniasis is a zoonotic disease and one of the most widespread diseases in our country. This illness is a significant public health concern in most Iranian provinces. Therefore, it is necessary to study the prevalence and identification of new sources of this problem in many regions of Iran. The present study was intended to investigate the epidemiology of cutaneous leishmaniasis in Yazd city.

Methods: This descriptive-analytical and cross-sectional study was performed on 121 patients with leishmaniasis in Nicopoor Center, Yazd in 2017. According to ethical and research standards, information about patients, including their gender, age, occupation, location and number of lesions and month of illness were collected and evaluated using SPSS Statistics, Version 21. Results: The highest incidence of leishmaniasis occurred in adults over 50 years of age (28.9\%) and in children under the age of 10 (23.1\%). An incidence of $41.3 \%$ was observed for other occupations, including driver, farmer and child. In second place, the highest frequency was related to housewives (25.6\%), and in third place, a higher frequency was observed in students (19\%). The most common venereal sites were the hands (38.8\%), in second place the feet $(28.1 \%)$ and in third place the face (15.7\%). The highest seasonal frequency of leishmaniasis occurred during the autumn.

Conclusion: In light of the current study findings and the adverse effects of leishmaniasis, it is necessary to design strategies with the aim of controlling the disease and to implement appropriate actions with the intention of decreasing its prevalence nationally.
\end{abstract}

Keywords: Cutaneous leishmaniasis, epidemiology, Yazd

ÖZ

Amaç: Zootonik bir hastalık olan kutanöz leishmaniasis, İran'daki en önemli endemik hastalıklardan biridir. Bu hastalık, ülkenin birçok ilinde önemli bir sağllk sorunudur. Bu nedenle, İran'ın pek çok bölgesinde bu hastalığa neden olan yeni kaynakların yaygınlığını ve hastalığın tanımlanması gibi konuları incelemek gerekmektedir. Bu çalışmada İran'ın Yezd kentindeki kutanöz leishmaniasis epidemiyolojisi araştırılmıştır.

Yöntemler: Bu kesitsel tanımlayıc1-analitik çalışma, 2017 yılında Nicopoor Center, Yezd'de leishmaniasis hastaları üzerinde gerçekleştirilmiştir. Etik ve araştırma standartlarına göre; yaş, cinsiyet, meslek, lezyon sayısı, lezyon yeri ve hastalığın ortaya çıtığı ay gibi bilgiler hasta grubundan toplandı ve toplanan veriler SPSS sürüm 21 programının standart istatistiksel paketi kullanilarak analiz edildi.

Bulgular: En yüksek leishmaniasis insidans1, 50 yaşın üzerindeki yetişkinlerde $(\% 28,9)$ ve 10 yaşın altındaki çocuklarda $(\% 23,1)$ görülmekte idi. Şoför, çiftçi ve çocuk da dahil olmak üzere diğer meslek gruplarında \%41,3 oranında bir artı̧̧ gözlendi. İkinci en yüksek görülme sıklığı \%25,6 ile ev hanımı hasta grubu ile ilişkiliydi ve üçüncü sırada ise \%19 oranı ile öğrenciler bulunmaktaydı. En yaygın zührevi bölgeleri; birinci sırada eller $(\% 38,8)$, ikinci sırada ayaklar $(\% 28,1)$ ve üçüncü sırada yüz $(\% 15,7)$ oluşturmakda idi. En yüksek leishmaniasis sıklığı sonbahar mevsiminde görülmekteydi.

Sonuç: Çalışmanın sonuçları ve leishmaniasis'in olumsuz etkileri değerlendirilerek, hastalığı kontrol etmek için yeni stratejilerin tasarlanması ve hastalık insidansını azaltmak için uygun eylemlerin uygulanması gerekli görülmektedir.

Anahtar Kelimeler: Kutanöz leishmaniasis, epidemiyoloji, Yezd

Received/Geliş Tarihi: 03.02.2020 Accepted/Kabul Tarihi: 08.12.2020

Address for Correspondence/Yazışma Adresi: Seyed Hossein Shahcheraghi, Infectious Diseases Research Center, Shahid Sadoughi Hospital,

Shahid Sadoughi University of Medical Sciences, Infectious Diseases, Yazd, Iran

E-mail/E-posta: shahcheraghih@gmail.com ORCID ID: orcid.org/0000-0003-1399-5222

${ }^{0}$ Copyright 2021 Turkish Society for Parasitology - Available online at www.turkiyeparazitolderg.org

${ }^{\circ}$ Telif hakkı 2021 Türkiye Parazitoloji Derneği - Makale metnine www.turkiyeparazitolderg.org web sayfasından ulașılabilir. 


\section{INTRODUCTION}

Human leishmaniasis is the third most serious disease carried by the arthropod in terms of global disease burden (1-3).

It is caused by a trypanosomatid protoza belonging to one of the more than 20 species of Leishmania currently known. Intracellular parasites corresponding to mandatory Leishmania genus associate with the members of the Trypanosomatidae family (order as titled Kinetoplastida), and above 20 classes worlwide create this vector-borne tropical/subtropical infection $(4,5)$.

Clinical symptoms of infection are established by the infection agent's (classes and likely specific strain) properties and the immunological condition of the patient. Disease is classified as three types including mucocutaneous (MCL), cutaneous form (CL) or visceral type (VL). After curing infection, the patients with VL could sometimes suffer the pos-kala-azar dermal leishmaniasis $(6,7)$.

CL is widespread in almost 97 countries that are in America (central areas), Asia, Southern Europe, Africa $(6,8)$. An estimated 12-15 million people suffer from leishmaniasis. Two million fresh patients of infection are discovered every year, of whic about 500,000 are individuals diagnosed with VL and about 1.5 million with CL $(1,9)$.

Some cases of CL have occurred in Iran, Colombia, Brazil, Algeria, Afghanistan, Pakistan, Syria, Saudi Arabia and Peru (10-12).

The type of cutaneous infection is the prevalent form of the illness, and the origin of infection in Iran is related to 1.000 years ago; the period of Avicenna, an Iranian famous doctor (1). In our region, two types of CL are frequent: skin type as anthroponotic (dry form or urban) and zoonotic (wet kind or rural) produced by L. tropica and L. major, separately (1). In spite of the rudimentary evidences on the epidemiology, main vectors and agents of transmitting the infection is well known, CL type remains a severe fitness difficulty in our country and the number of cases is growing in some parts of the country (1).

The current research is a study by data got from Yazd Nicopoor health center. The aim of the present paper is to investigate cutaneous leishmaniasis epidemiology in Yazd province.

\section{METHODS}

\section{The Population and Area of Study}

Yazd is one of the central provinces of Iran country. This descriptive-analytical and cross-sectional research was performed on 121 individuals with leishmaniasis in Nicopoor Center, Yazd in 2017

\section{Research Method}

According to the ethical and research standards, information about patients such as age, sex, occupation, location and number of lesion and season (Spring, Summer, Autumn, and Winter) were collected by a questionnaire. All cases identified with CL wound in Nicopoor center of the Yazd during 2017 were enrolled in our study. The study was approved by the Ethics Committee of the Shahid Sadoughi University of Medical Sciences, Yazd, Iran.

\section{Statistical Analysis}

Collected data were documented in a series questionnaires and analysis was performed by the standard packages SPSS version 21 and ANOVA test.

\section{RESULTS}

During the period of observation, 121 patients were referred in 2017, from which 70 (57.9\%) were male and 51 (42.1\%) were female. The mean age of patients was $34.51 \pm 24.6$ years within the range of 1 to 85 years.

Among the cases, we determined 32 cases (26.4\%) with underlying diseases such as diabetes, hypertension, heart failure and rheumatologic diseases. The 121 patients considered in our study, exhibited a total of 255 ulcers in their limbs and body. Smear was performed for all patients and only $2(1.7 \%)$ cases had negative result. Among patients that were observed in our study, $19(15.7 \%)$ of them had affected family members, also only 2 cases $(1.7 \%)$ had a history of scarring.

The highest prevalence of cutaneous leishmaniasis was observed in patients over 50 years old (28.9\%) and children under 10 years old (23.1\%) (Table 1).

Frequency distribution of cutaneous leishmaniasis in Yazd according with the jobs of the patients showed that 50 (41.3\%) of affected people had different jobs including driver, farmer and child (Table 2). The most common locations of the injuries caused by the disease were the hands (38.8\%) and at the second place the foots (28.1\%) (Table 3).

Of the patients with more than 4 lesions, 1 case had 15 lesions and the remainder had between 4 to 10 lesions (Table 4).

The most frequent prevalence of cutaneous leishmaniasis according with the season was occurred by the autumn (33.1\%) (Table 5).

\section{DISCUSSION}

Leishmaniasis infection is a tropical areas illness produced by the Leishmania agent and transferred via the sandflies of Phlebotominae subfamily (13-15).

Table 1. The prevalence of cutaneous form according with the age

\begin{tabular}{|l|l|l|}
\hline Age group (year) & Number & Percent (\%) \\
\hline$<10$ & 28 & 23.1 \\
\hline $11-20$ & 17 & 14 \\
\hline $21-30$ & 12 & 9.9 \\
\hline $31-40$ & 12 & 9.9 \\
\hline $41-50$ & 17 & 14 \\
\hline$>50$ & 35 & 28.9 \\
\hline Total & 121 & 100 \\
\hline
\end{tabular}

Table 2. The prevalence of cutaneous form of disease based on the profession

\begin{tabular}{|l|l|l|}
\hline Profession & Number & Percent (\%) \\
\hline Housewives & 31 & 25.6 \\
\hline Student & 23 & 19 \\
\hline Worker & 10 & 8.3 \\
\hline Employee & 6 & 5 \\
\hline Unemployed & 1 & 0.8 \\
\hline $\begin{array}{l}\text { Other occupations (driver, } \\
\text { farmer and child) }\end{array}$ & 50 & 41.3 \\
\hline Total & 121 & 100 \\
\hline
\end{tabular}


CL form is the most prevalent type of leishmaniasis infection and it creates the lesions in the skin in the unprotected areas of the human body, presenting lesions as lifetime. Around $90 \%$ of patients of CL happen in the Mediterranean, the Americas, Central Asia and the Middle East $(16,17)$. Almost $70 \%$ of novel individuals of $C L$ type take place in the main six countries including Iran, Colombia, Brazil, Syria, Afghanistan and Algeria $(16,18)$.

Our study in the central area of Iran (Yazd) showed that the maximum occurrence of leishmaniasis infection is observed in people over 50 years old and children under the age of 10 . Drivers, farmers and children were the individuals more affected by $C L$ with $41.3 \%$. Also, the highest frequency was observed in the housewives. The most common lesions sites were the hands and the foots. The highest frequency of leishmaniasis occurred by the autumn and at the second place by summer.

A study was conducted with the aim to evaluate CL's status and the environmental determinants and to evaluate the level of consciousness of rural populations in areas with the high incidence in the northern Ethiopia (Tigray). The occurrence of $\mathrm{CL}$ as localized was $2.3 \%$ (maximum $4.7 \%$ ), with noticeable changes between the villages. Almost $21 \%$ had wounds because of the earlier contaminations. Although the risk was no genderdependent, the infection occurrence was meaningfully more in the ages of $0-9$ (4.5\%) and 10-19 (2.5\%), higher limbs (13\%), and

Table 3. The prevalence of cutaneous leishmaniasis according to the part of the body affected by the disease

\begin{tabular}{|l|l|l|}
\hline Member involved & Number & Percent (\%) \\
\hline Face & 19 & 15.7 \\
\hline Hand & 47 & 38.8 \\
\hline Foot & 34 & 28.1 \\
\hline Trunk & 4 & 3.3 \\
\hline Trunk and organs & 5 & 4.1 \\
\hline Face and organs & 7 & 5.8 \\
\hline Hand and foot & 5 & 4.1 \\
\hline Total & 121 & 100 \\
\hline
\end{tabular}

Table 4. The prevalence of cutaneous leishmaniasis according with the number of lesions due to the disease

\begin{tabular}{|l|l|l|}
\hline Number of lesions & Number & Percent (\%) \\
\hline One & 69 & 57 \\
\hline Two & 27 & 22.3 \\
\hline Three & 9 & 7.4 \\
\hline Over four & 16 & 13.3 \\
\hline Total & 121 & 100 \\
\hline
\end{tabular}

Table 5. The prevalence of cutaneous leishmaniasis according the season

\begin{tabular}{|l|l|l|}
\hline Season & Number & Percent (\%) \\
\hline Spring & 26 & 21.5 \\
\hline Summer & 28 & 23.1 \\
\hline Autumn & 40 & 33.1 \\
\hline Winter & 27 & 22.3 \\
\hline Total & 121 & 100 \\
\hline
\end{tabular}

the patient face (82\%) and were primarily affected by the disease agent. Approximately $11 \%$ of families had one or several patients related to CL and this subject was attributed to nearness to the habitations of hyrax. All of the applicants were aware of the scars, nonetheless, were unaware of the way of spread of the disease and its relation with hyraxes types (19).

Another research aimed at defining the epidemiological, etiological and clinical features of CL type detected in children hospital at the Casablanca University. One hundred six patients with CL type were identified, of which 40 (38\%) in children: 29 because of L. tropica (72.5\%), 4 because of L. infantum (10\%), and also 7 because of $L$. major (17.5\%). CL form initiated by L. tropica agent was considerably related to low age and was characterized via the high prevalence of the nodular type and a facial site. CL lesions in childhood were distinguished by minor mass and facial position compared to adults. Children were predominantly cured with the antimonials with strong protection and a considerable clinical reply (20).

The aim of a study was to update epidemiological data and check for CL risk factors. 59.3\% of those were patients from Brazil, mainly gold metal mineworkers. $58 \%$ of patients (maximum) were 16 and 40 years old, and men were more (69\%). In traditional wooden houses a large proportion of patients stayed (51\%). Throughout journeys to areas with the highest patients in seaside cities were generally contaminated $(60 \%)$ and had shorter diagnostic time than hinterland workers. The attendance of a marine source (40\%) and dogs nearby households (40\%) was often described among environmental risk factors. $80 \%$ of patients were involved by Leishmania guyanensis, afterwards accompanied by L. braziliensis (6\%), and L. naiffi (2\%) (21).

Another study examined epidemiological aspects of CL in Kashan, central Iran, during an 8-year period (2009-2016). The highest annual incidence in 2009 was measured at 182/100,000 people, and also the lowest in 2016 (47/100,000 cases). The most rates among age groups affected have been detected in 20-29 year-old patients (almost 21\%). In excess of $51 \%$ of the cases were under 30 years old. The most frequency of the illness, 1.134 (43.3\%), was recognized in autumn season. Hands (61.4\%) were the most usual site of scars (10).

In another analysis the occurrence and epidemiological features of CL form in southwestern Iran from 2014 to 2017 were also assessed. In Abadan and Khorramshahr cities, 151 and 132 positive patients for CL type were found, separately. The most incidence of disease was detected in both cities in the winter, between men and urban dwellers. The occurrence of CL based on age distribution was more in the 20-30 year age range than others. In fact, the hands and feet were the most frequent organs complicated (4).

Afterward 30 years of epidemic of disease in Maroc, a research was performed to examine the present ecological and epidemiological situations. This infection affected both sexes and individuals from all ages, with small rates of children and women. More importantly, the vulnerable age range among females was greater than among males, and this disparity was further noticeable in Fquih Ben Salah, where the infection had increased recently. Likewise, age groups at threat were greater and altered meaningfully each year, especially in the fresh developing parts of infection (22).

A study examined epidemiological characteristics of CL infection in Aran va Bidgol area, in the region of Isfahan, Iran. 926 patients were reported that included 542 (58.5\%) men and 384 (almost 
42\%) a female with proved infection. CL type was more prevalent among men (58\%). In 2009 and 2016, the maximum and minimum occurrence of infection was measured at approximately 238.5 and 44.2 per 100,000 people, respectively. The most prevalence of infection was detected in the 0-9-year age group (26.3\%). Many cases were recognized in the autumn season (54\%). More scars were observed on the patients hands (44.7\%) (23).

\section{CONCLUSION}

Because of high prevalence of CL in hands and autumn season in our city, it seems to be necessary to plan for controlling disease and to implement appropriate plans with the aim of decrease the incidence of the infection. Control strategies such as educational campaigns, general health improvement, the fight against the reservoir, and environmental care are proposed with the aim to control the disease.

\section{ACKNOWLEDGEMENTS}

The authors thank infectious diseases research center of Yazd, Iran for their contribution. All patients filled informed consent forms.

\section{* Ethics}

Ethics Committee Approval: The study was approved by the Ethics Committee of the Shahid Sadoughi University of Medical Sciences, Yazd, Iran (2016-2017).

Informed Consent: All patients filled informed consent forms. Peer-review: Internally peer-reviewed.

\section{* Authorship Contributions}

Concept: J.A., Design: J.A., Data Collection or Processing: Z.A., A.T., Analysis or Interpretation: A.T., S.H.S., Literature Search: Z.A., Writing: S.H.S.

Conflict of Interest: No conflict of interest was declared by the authors.

Financial Disclosure: The authors declared that this study received no financial support.

\section{REFERENCES}

1. Akhlagh A, Salehzadeh A, Zahirnia AH, Davari B. 10-Year Trends in Epidemiology, Diagnosis, and Treatment of Cutaneous Leishmaniasis in Hamadan Province, West of Iran (2007-2016). Front Public Health 2019; 7: 27.

2. Al-Jawabreh A, Dumaidi K, Ereqat S, Al-Jawabreh H, Nasereddin A, Azmi $\mathrm{K}$, et al. Molecular epidemiology of human cutaneous leishmaniasis in Jericho and its vicinity in Palestine from 1994 to 2015. Infect Genet Evol 2017; 50: 95-101.

3. McIlwee BE, Weis SE, Hosler GA. Incidence of Endemic Human Cutaneous Leishmaniasis in the United States. JAMA Dermatol 2018; 154: 1032-9.

4. Soltani S, Foroutan M, Hezarian M, Afshari H, Kahvaz MS. Cutaneous leishmaniasis: an epidemiological study in southwest of Iran. J Parasit Dis 2019; 43: 190-7.

5. Jariyapan N, Daroontum T, Jaiwong K, ChanmolW, Intakhan N, Sor-Suwan $\mathrm{S}$, et al. Leishmania (Mundinia) orientalis n. sp. (Trypanosomatidae), a parasite from Thailand responsible for localised cutaneous leishmaniasis. Parasit Vectors 2018; 11: 351.
6. Söbirk SK, Inghammar M, Collin M, Davidsson L. Imported leishmaniasis in Sweden 1993-2016. Epidemiol Infect 2018; 146: 1267-74

7. Asmaa Q, Al-Shamerii S, Al-Tag M, Al-Shamerii A, Li Y, Osman BH. Parasitological and biochemical studies on cutaneous leishmaniasis in Shara'b District, Taiz, Yemen. Ann Clin Microbiol Antimicrob 2017; 16: 47.

8. Pavli A, Maltezou HC. Leishmaniasis, an emerging infection in travelers. Int J Infect Dis 2010; 14: 1032-9.

9. Al-Bajalan MMM, Al-Jaf SMA, Niranji SS, Abdulkareem DR, Al-Kayali KK, Kato H. An outbreak of Leishmania major from an endemic to a non-endemic region posed a public health threat in Iraq from 2014-2017: Epidemiological, molecular and phylogenetic studies. PLoS Negl Trop Dis 2018; 12: 0006255

10. Moein D, Masoud D, Saeed M, Abbas D. Epidemiological Aspects of Cutaneous Leishmaniasis during 2009-2016 in Kashan City, Central Iran. Korean J Parasitol 2018; 56: 21-4.

11. Sofizadeh A, Rassi Y, Vatandoost H, Hanafi-Bojd AA, Mollalo A, Rafizadeh $S$, et al. Predicting the Distribution of Phlebotomus papatasi (Diptera: Psychodidae), the Primary Vector of Zoonotic Cutaneous Leishmaniasis, in Golestan Province of Iran Using Ecological Niche Modeling: Comparison of MaxEnt and GARP Models. J Med Entomol 2017; 54: 312-20.

12. Piroozi B, Moradi G, Alinia C, Mohamadi P, Gouya MM, Nabavi M, et al. Incidence, burden, and trend of cutaneous leishmaniasis over four decades in Iran. Iranian Journal of Public Health 2019; 48: 28-35.

13. Mubayi A, Paredes M, Ospina J. A comparative assessment of epidemiologically different cutaneous leishmaniasis outbreaks in Madrid, Spain and Tolima, Colombia: an estimation of the reproduction number via a mathematical model. Tropical medicine and infectious disease 2018; 3: 43 .

14. Alvar J, Yactayo S, Bern C. Leishmaniasis and poverty. Trends Parasitol 2006; 22: 552-7

15. Akhoundi M, Kuhls K, Cannet A, Votýpka J, Marty P, Delaunay P, et al. A Historical Overview of the Classification, Evolution, and Dispersion of Leishmania Parasites and Sandflies. PLoS Negl Trop Dis 2016; 10: 0004349.

16. Ramírez JD, Hernández C, León CM, Ayala MS, Flórez C, González C. Taxonomy, diversity, temporal and geographical distribution of Cutaneous Leishmaniasis in Colombia: A retrospective study. Sci Rep 2016; 6: 28266.

17. Al-Salem WS, Pigott DM, Subramaniam K, Haines LR, Kelly-Hope L, Molyneux DH, et al. Cutaneous Leishmaniasis and Conflict in Syria. Emerg Infect Dis 2016; 22: 931-3.

18. Reithinger R, Dujardin JC, Louzir H, Pirmez C, Alexander B, Brooker S. Cutaneous leishmaniasis. Lancet Infect Dis 2007; 7: 581-96.

19. Yohannes M, Abebe Z, Boelee E. Prevalence and environmental determinants of cutaneous leishmaniasis in rural communities in Tigray, northern Ethiopia. PLoS Negl Trop Dis 2019; 13: 0007722.

20. Baghad B, Riyad M, Razanapinaritra R, Maksouri H, Ben Errais H, Chiheb S. La leishmaniose cutanée de l'enfant au Maroc: particularités cliniques et épidémiologiques [Pediatric cutaneous leishmaniasis in Morocco: Clinical and epidemiological features]. Ann Dermatol Venereol 2020; 147: 106-12.

21. Loiseau R, Nabet C, Simon S, Ginouves M, Brousse P, Blanchet D, et al. American cutaneous leishmaniasis in French Guiana: an epidemiological update and study of environmental risk factors. Int J Dermatol 2019; 58 : 1323-8.

22. Abou-Elaaz FZ, Outourakht A, Bouhout S, Himmi O, Guernaoui S. Thirty years of cutaneous leishmaniasis in Tadla-Azilal focus, Morocco. Parasite Epidemiol Control 2019; 4: 00091.

23. Moein D, Masoud D, Mahmood N, Abbas D. Epidemiological Trend of Cutaneous Leishmaniasis in an Endemic Focus Disease During 20092016, Central Iran. Turkiye Parazitol Derg 2019; 43: 55-9. 